\title{
An Analysis of Metaphor Translation in the Subtitle of Sherlock Holmes 2: A Game of Shadows (2011) Movie
}

\author{
Siegfrieda A. S. Mursita Putri \\ siegfrieda@ukrida.ac.id \\ Faculty of Humanities and Social Sciences, Universitas Kristen Krida Wacana \\ Martha \\ marthasie1996@gmail.com \\ Faculty of Humanities and Social Sciences, Universitas Kristen Krida Wacana
}

\begin{abstract}
Metaphor has been a conflict in subtitling for its cultural-specific sense and challenging translatability. Consequently, the translators tend to omit the metaphors. This study attempts to find out the categories of conceptual metaphors and applied strategies in the subtitles of Sherlock Holmes 2: A Game of Shadows (2011). This study applies Combined Strategies proposed by Lindqvist (Pedersen, 2015). The results indicate that analogy, personification, and image metaphors appear in the movie. The translator applies five of nine proposed strategies in this study. The most frequently applied strategies are word-for-word translation and paraphrase strategies. No omission occurs, but the study discovers that the translation appears to be less natural and fails to transfer the cultural essence from the English metaphors.
\end{abstract}

Keywords: combined strategies, conceptual metaphor

\section{INTRODUCTION}

Metaphor translation has been a source of discussion since there are some concerns as regards metaphors (TaheriArdali, Bagheri, \& Eidy, 2013). Metaphor is considered unimportant and significant in a poetic translation only. Consequently, metaphors are often omitted (Ibid). Dickins (2005) points out that though general studies of metaphors have developed over those twenty five years, metaphor translation has only got little attention. Moreover, in subtitling, the limited time and space to display should be considered (Pedersen, 2015).

It is arguable, however, that metaphor is in fact essential to be translated (lbid; Dickins, 2005; TaheriArdali et al., 2013). Metaphor is noticeable and universal in particular languages due to similar aspects of human experiences, for example, "our relationship has found a dead-end street" uses a concept of journey to depict the love relationship (Dickins, 2005; Israel, 2014; Lakoff, 1993; Schmidt, 2014). It can explain something abstract (e.g.: time and emotion) and some common words will suffer without metaphorical expressions (e.g.: "radiantly happy" comprises the concept of light to visualize how happy the person is). On the other hand, metaphor is known to be cultural-specific to one language or group (Schmidt, 2014). Take "couch potato" for example. It is only familiar in the western countries. Specifically, in translation or subtitles, it helps the audience to get the cultural essence of the movie and colorizes the monologues or dialogues (Ibid; Israel, 2014).

As regards the movie chosen in this study, Sherlock Holmes 2: A Game of Shadows, the frequent use of metaphors is the main characteristic of this movie (Lu, 2009). The metaphors are mostly distinctive and challenging to be translated that omission is not recommended. Moreover, "Sherlock Holmes 2" achieved USD 545.4 million in the box offices, as recorded by Internet Movie Database or IMDb (2011). The series have gained numerous fans that the third sequel will be launched in 2020. These are why the researcher believes that the movie is still relatable and valid to be researched.

\section{Metaphor}

Metaphor is a figurative word or phrase describing something complex using a simpler concept by means of 
similarity (Dickins, 2005; Pedersen, 2015). Metaphor has some distinctive characteristics. First, it has a noticeable figurative language and a strong emotion to be expressed; for example, "the citizens slammed the President" (Dickins, 2005). Second, some metaphors are shared in particular languages and cultures (universal), but some are not which make them into cultural-specific items (Israel, 2014; Schmidt, 2014). For instances, "heart of gold" is shared between English and Indonesian culture and translated into "heart of gold" or "berhati emas" while "a piece of cake" is non-shared and translated into "very easy" or "sangat mudah" in Indonesian. Third, metaphors colorize plain ideas and literary products, such as novels, movies, etc. (Israel, 2014). Metaphors are vivid and clear to be imagined whereas there are some considerably basic abstract ideas which are hard to be expressed without metaphors. For instance, "deeply happy" uses a spatial word to describe how happy the person is.

In this study, metaphor is divided into two types: conceptual metaphor and metaphorical expression. Lakoff (1993) explains that conceptual metaphor is simply illustrated in this notion, "Target domain $X$ is source domain $Y$ ". For instance, "life is a rollercoaster". Life is the target domain, and a rollercoaster is the source domain to conceptualize what life is. The concept of "up and down" of life is analogized with a rollercoaster. There are four categories of metaphors (Lakoff, 1993). The first is an image metaphor which can be visualized with senses (e.g.: "her lips are rosebuds"). Second, personification shows that a dead object can act as a living object (e.g.: "my house is a friend that protects me"). Third, proverb is an old saying to express truth and advice (e.g.: "early bird catches the worm"), and fourth, analogy is a direct conceptualization between two resembling objects (e.g.: "my school is a jail").

On the other hand, a metaphorical expression involves similarity of something to explain a notion, used as a part of the sentence and natural in use. For example, the concept of journey depicts love relationships, "Our relationship has found a dead-end street." (Lakoff, 1993; Taheri-Ardali et al., 2013).

\section{Metaphor Translation}

Translation is a process and a product of transferring a source language (SL) into a target language (TL) by a translator in a particular socio-cultural context (Nida, 1964). Metaphor translation is the process, product, and cognitive aspect of uncovering and rebuilding the complexity of metaphors into TL and its culture (Taheri-Ardali et al., 2013). Subtitling metaphors is a special kind of translation in which cultural contexts, audio visual aspects, and movie plot are contributing in conceptualizing the meaning (Pedersen, 2015).

The conditions of subtitling should also be taken into account. Referring to Pedersen (2015), first, subtitles should involve only $36-40$ characters each line, including punctuations and blank spaces. The maximum lines are two for every speech length and transition. Second, the subtitles should stand for twelve characters per second. This golden rule is considered convenient for audiences while processing the on-screen images and subtitles simultaneously. Third, adjusting the message from SL into TL involves clearing pauses, repetition, and false starts.

In translation, metaphor is perceived negatively for its nature to be culturalspecific and challenging in the matter of translatability. Thus, most translators tend to avoid it (Taheri-Ardali et al., 2013). On the other hand, Newmark, quoted by Dickins (2005), affirms that while the main problem of translation is choosing the translation methods, the most important kind of translation is the metaphor translation. This notion suggests that metaphor translation is important, and instead of avoiding it, translating it will be considered more professional (Ibid; Taheri-Ardali et al., 2013). Lindqvist and Dagut, quoted by Pedersen (2015), also rebut that if metaphor is ignored, loss of figurative language and dynamic and strong emotion possessed by the metaphors will occur. 


\section{Combined Strategies}

This study affirms that metaphor translation is absolutely complex and needs detailed translation strategies to handle it. Adapted from Toury's and Van Den Broeck's theories and combined by Lindqvist, Combined Strategies to analyze metaphor translation are applied in this study (Pedersen, 2015):

\section{a. Word-for-word Translation}

SL metaphor is literally translated into $\mathrm{TL}$.

ST: Time is a thief

TT: Waktu adalah pencuri

[literal translation: time is a thief]

b. Substitution

SL metaphor is directly translated into TL metaphor.

ST: Broken heart

TT: Patah hati

[literal translation: broken heart]

c. Paraphrase

$\mathrm{SL}$ metaphor is translated into TL non-metaphorical expression.

ST: Fade off to sleep

TT: Tertidur

[literal translation: asleep]

\section{d. Compensation 1}

SL non-metaphorical expression is translated into TL metaphor.

ST: Court

TT: Meja hijau

[literal translation: green table]

e. Compensation 2

No SL metaphor. Thus, metaphor from TL is added.

f. Specification

SL metaphor is retained and explained.

g. Retention

SL metaphor is retained as it is.

h. Omission
SL metaphor is deleted.

\section{Comparison to Schmidt's and Taheri- Ardali et al.'s Case Studies}

In Goran Schmidt's study, Schmidt (2014) analyzed visualized metaphors which involve gesture and face expression to determine the meaning in TL. To assist his case study on the English subtitles of a Croatian movie, Schmidt applied the translation strategies of Conceptual Metaphor Theory (CMT), initially proposed by Lakoff and Johnson in 1980. Schmidt (2014) emphasized that universality affects the translator's strategies. Most shared metaphors are translated into the same conceptual metaphors and the nonshared ones into different conceptual metaphors and paraphrase. However, the study finds out that these strategies not adequate to observe the study object. The result is less specific, predictable and needs more complete strategies to present a more thorough result.

Taheri-Ardali et al.'s study (2013) shows that metaphor is formed by sociocultural beliefs and attitudes to particular cultures based on cognitive equivalence. In their case study, they analyzed all varieties of metaphor expressions and the translation results from the screenplay of Godfather I. The applied strategy is Cognitive Theory Hypothesis (CTH) by Kovecses in 2005. The result of this study shows that the data analysis does not agree with the basic hypothesis and that it suggests that additional models should be added to the scheme. Since the metaphors were not detailed further, the object of their study is considered to be too broad.

After reviewing those two related studies, this study sets a perimeter that it does not cover visualized metaphors which are addressed in Schmidt's study. Also, this study has provided a more thorough explanation of division of the conceptual metaphors to fill in the gap in Taheri-Ardali et al.'s study. As a comparison to Combined Strategies (Pedersen, 2015) applied in this study, CMT are all included in the aforementioned strategies. On the other 
hand, the study suggests that $\mathrm{CTH}$ is covered in the Combined Strategies, but covers less than what the Combined Strategies can do.

Despite these, after comparing the translation strategies of $\mathrm{CMT}, \mathrm{CTH}$, and Combined Strategies, the study would like to divide the substitution strategy into two: a) substitution 1, in which SL metaphor is translated into the same conceptual metaphor in TL and b) substitution 2, in which SL metaphor is translated into the different conceptual metaphor. The division is taken considering that the substitution bears a broad scope which can be narrowed down with the divisions. This division completes what the combined strategies have developed to make the data analysis more precise.

\section{METHOD}

This case study was done qualitatively. The primary sources were the subtitles in the movie in the form of a Blu-ray Disc format distributed by Warner Bros Home Video, released in 2012. The duration is 128 minutes. The specific object of this study is all conceptual metaphors in the movie. The source text (English subtitle) and the target text (Indonesian subtitle) were aligned in a table and analyzed in terms of conceptual metaphor categories such as analogy, personification, image metaphor, and proverb and Combined Strategies proposed by Lindqvist, adapted from Toury's and Van Den Broeck's (Pedersen, 2015).

To collect the data, the researcher watched the movie by adjusting the subtitle to the English one. After that, the researcher paid a close attention to each line of the subtitles appearing in the movie and took notes when any conceptual metaphors appear. After listing down the ST metaphors and duration of their lines, the researcher began replaying the movie from the beginning. The researcher adjusted the subtitle to the Indonesian one. Likewise, the researcher paid a close attention to the translation and aligned it next to the English metaphors. Afterwards, the time frame was noted, double-checked and assisted with the written English subtitles archived in Subscene.

For the analysis, the subtitled conceptual metaphors were categorized into the metaphor categories and the applied translation strategies: word-forword translation, substitution, etc. The result was presented mostly descriptively, but it may present percentages (numerical) only to emphasize the extent of each strategy applied in the translation of the movie. The illustrations are as seen in Table 1 and 2.

Table 1

Analysis of Translation Strategies for Conceptual Metaphors

\begin{tabular}{|c|c|c|c|c|c|c|}
\hline \multicolumn{6}{|c|}{ Conceptual Metaphors } & \multirow{3}{*}{$\begin{array}{l}\text { Transl } \\
\text { ation } \\
\text { Strate } \\
\text { gy }\end{array}$} \\
\hline \multicolumn{4}{|c|}{ ST } & \multirow{2}{*}{$\begin{array}{c}\text { Time } \\
\text { Fram } \\
\text { e }\end{array}$} & \multirow[t]{2}{*}{ TT } & \\
\hline $\begin{array}{c}\text { ima } \\
\text { ge }\end{array}$ & $\begin{array}{c}\text { person } \\
\text { ificatio } \\
n\end{array}$ & $\begin{array}{c}\text { analo } \\
\text { gy }\end{array}$ & $\begin{array}{c}\text { pro } \\
\text { ver } \\
\mathrm{b}\end{array}$ & & & \\
\hline & & $\begin{array}{l}\text { He's } \\
\text { the } \\
\text { Napo } \\
\text { leon } \\
\text { of } \\
\text { crime } \\
\text {. }\end{array}$ & & $\begin{array}{l}00: 0 \\
7: 30- \\
00: 0 \\
7: 35\end{array}$ & $\begin{array}{l}\text { Dia } \\
\text { penja } \\
\text { hat } \\
\text { kelas } \\
\text { berat. }\end{array}$ & $\begin{array}{l}\text { parap } \\
\text { hrase }\end{array}$ \\
\hline & & $\begin{array}{l}\text { Don't } \\
\text { be a } \\
\text { dingy } \\
\text { bird }\end{array}$ & & $\begin{array}{l}00: 1 \\
7: 07- \\
00: 1 \\
7: 10\end{array}$ & $\begin{array}{l}\mathrm{Si} \\
\text { bodoh }\end{array}$ & $\begin{array}{l}\text { parap } \\
\text { hrase }\end{array}$ \\
\hline & & $\begin{array}{l}\text { Marri } \\
\text { age } \\
\text { is the } \\
\text { end, } \\
\text { I tell } \\
\text { you. }\end{array}$ & & $\begin{array}{l}00: 1 \\
8: 58- \\
00: 1 \\
9: 01\end{array}$ & $\begin{array}{l}\text { Pernik } \\
\text { ahan } \\
\text { itu } \\
\text { suatu } \\
\text { akhir, } \\
\text { kuberi } \\
\text { tahu } \\
\text { kau. }\end{array}$ & $\begin{array}{l}\text { word- } \\
\text { for- } \\
\text { word }\end{array}$ \\
\hline
\end{tabular}

Table 2

The Extent (Percentage) of Each Strategy

\begin{tabular}{|l|l|l|}
\hline $\begin{array}{l}\text { Translation } \\
\text { Strategy }\end{array}$ & Frequency & Percentage \\
\hline Word-for-word & & $\%$ \\
\hline Substitution 1 & & $\%$ \\
\hline Substitution 2 & & $\%$ \\
\hline Paraphrase & & $\%$ \\
\hline $\begin{array}{l}\text { Compensation } \\
1\end{array}$ & & $\%$ \\
\hline $\begin{array}{l}\text { Compensation } \\
2\end{array}$ & $\%$ \\
\hline Specification & & $\%$ \\
\hline Retention & & $\%$ \\
\hline Omission & & $\%$ \\
\hline
\end{tabular}




\section{Results}

The result shows that there are sixty-six metaphorical expressions and forty-two conceptual metaphors. The examples of the metaphorical expressions are "their motives are highly unsavory", "sickly-sweet nanny", and "mirrored truth", which are not covered in this study (Lakoff, 1993; Silver et al. \& Ritchie, 2011; Taheri-Ardali et al., 2013). Also, there are thirty-two analogies, nine personifications, one image metaphor, and no proverb. There are five strategies found in the analysis, i.e. word-for-word translation, substitution 1, substitution 2, paraphrase, and compensation 2 as seen in Table 3 .

Table 3

The Extent of Each Strategy

\begin{tabular}{|c|c|c|c|}
\hline $\begin{array}{l}\text { Numb } \\
\text { er }\end{array}$ & $\begin{array}{l}\text { Translatio } \\
\text { n Strategy }\end{array}$ & $\begin{array}{l}\text { Freque } \\
\text { ncy }\end{array}$ & $\begin{array}{l}\text { Percent } \\
\text { age }\end{array}$ \\
\hline 1 & $\begin{array}{l}\text { Word-for- } \\
\text { word }\end{array}$ & 18 & $42.86 \%$ \\
\hline 2 & $\begin{array}{l}\text { Substitutio } \\
\text { n } 1\end{array}$ & 6 & $14.29 \%$ \\
\hline 3 & $\begin{array}{l}\text { Substitutio } \\
\text { n } 2\end{array}$ & 1 & $2.38 \%$ \\
\hline 4 & $\begin{array}{l}\text { Paraphras } \\
\text { e }\end{array}$ & 16 & $38.09 \%$ \\
\hline 5 & $\begin{array}{l}\text { Compensa } \\
\text { tion } 1\end{array}$ & 0 & $0 \%$ \\
\hline 6 & $\begin{array}{l}\text { Compensa } \\
\text { tion } 2\end{array}$ & 1 & $2.38 \%$ \\
\hline 7 & $\begin{array}{l}\text { Specificati } \\
\text { on }\end{array}$ & 0 & $0 \%$ \\
\hline 8 & Retention & 0 & $0 \%$ \\
\hline 9 & Omission & 0 & $0 \%$ \\
\hline & Total & 42 & $100 \%$ \\
\hline
\end{tabular}

Word-for-word translation is the most applied strategy in the translation. Paraphrase is the second most applied strategy. Substitution 1 comes as the third one. Meanwhile, substitution 2 and compensation 2 are the least applied strategies of all. Compensation 1, specification, retention, and omission are not found. Each metaphor is translated, but the arising problem is whether or not the translated metaphors transfer the expected cultural essence from the movie.

As regards the absence of compensation 1 which translates SL non- metaphorical expression into $T L$ metaphor, in accordance with the researcher's experience as a student translator, this is probably because the translator could not find Indonesian metaphors which could convey the English expression. Then, specification and retention were not applied because the translator attempted to avoid displaying any English metaphors in the Indonesian subtitle so that it would be wholly in Indonesian and easier to comprehend. Lastly, the omission strategy was not applied because the metaphors used in the movie are mostly original or made up by the author himself and displayed frequently in the subtitles so that the translator could not omit those metaphors since it may fail to transfer the messages from each dialogue to the audiences (Lu, 2009).

\section{DISCUSSION}

Hereby each category of metaphor and strategy applied in this study are elaborated and discussed with some samples.

\section{Categories of Metaphor}

\section{a. Analogy}

This category appears the most in the movie. Analogy connects two resembling objects in one concept (Lakoff, 1993; Pedersen, 2015). To determine if the word or the phrase is an analogy, we take a look at the similar traits between both referred objects, as seen in example (1) and (2).

(1) ST: Sherlock Holmes: "It's a game, dear man, a shadowy game."

TT: Sherlock Holmes: "Ini permainan. Permainan rahasia." Back translation: "It's a game. A secret/shadowy game."

(Silver et al. \& Ritchie, 2011, 00:16:30 - 00:16:33)

In this case, it is inferred as an analogy because Holmes uses "a shadowy game" directly within his speech to refer to Prof. Moriarty's crime master plan. A game and a crime master plan have similarities, such as strategy and 
opponents. Moriarty is Holmes's nemesis who has a large criminal organization influencing all over the world. He is genius in mathematics, a famous author and a lecturer. Moriarty's plan in the movie is incredibly well-planned that one by one can be murdered without traces since he never makes a direct contact with the people he hires to murder his targets.

(2) ST: Sherlock Holmes: "We're playing cat and mouse, the professor and I."

TT: Sherlock Holmes: "Kita bermain kucing dan tikus, profesor dan aku." Back translation: "We're playing cat and mouse, the professor and I."

(Silver et al. \& Ritchie, 2011, 00:16:33 - 00:16:37)

On the other hand, "cat and mouse" is considered as an analogy as Holmes attempts to interfere with Moriarty's dark business, and thus, Moriarty is after him. "Cat and mouse" and "Moriarty and Holmes" in the movie have similar traits that they are chasing each other, and that they are enemies.

\section{b. Personification}

A metaphor is categorized as a personification if there is a dead object which is capable to act like a living thing. The objects use active verbs as if they can act like living things (Lakoff, 1993). Take (3) and (4) as examples.

(3) ST: "Cards can illuminate your past..."

TT: "Kartu bisa menggambarkan masa lalumu..."

Back translation: "Cards can illustrate your past..."

(Silver et al. \& Ritchie, 2011, 00:24:20 -

(4) ST: "When freedom triumphed over tyranny."

TT: "Ketika kemerdekaan menang atas kelaliman."

Back translation: "When freedom won over cruelty."

(Silver et al. \& Ritchie, 2011, 01:01:24 - 01:01:27)

c. Image Metaphor
This metaphor can be imagined with senses as seen in example (5).

(5) ST: Sherlock Holmes: "Then again, I'm knee-deep in research."

TT: Sherlock Holmes: "Aku terlalu sibuk dengan penelitianku."

Back translation: "I'm too busy with my research."

(Silver et al. \& Ritchie, 2011, 00:13:29 -

$00: 13: 32)$

This metaphor is categorized into an image metaphor since one may immediately imagine the person kneeling down while doing something, which can be inferred that the person is doing something seriously.

\section{Metaphor Translation Strategies}

a. Word-for-word Translation

This strategy is applied the most frequent of all. Based on the researcher's experience as a student translator, this may happen because word-for-word translation is the easiest strategy of all after omission. Some examples of the metaphors and their translation are shown in example (6) and (7):

(6) ST: Sherlock Holmes: "It's a game, dear man, a shadowy game."

TT: Sherlock Holmes: "Ini permainan. Permainan rahasia."

Back translation: "It's a game. A secret/shadowy game."

(Silver et al. \& Ritchie, 2011, 00:16:30 -

$00: 16: 33)$

(7) ST: Dr. Watson: "I thought it was spider and fly?"

TT: Dr. Watson: "Kukira namanya laba-laba dan lalat?"

Back translation: "I thought it was spider and fly?"

(Silver et al. \& Ritchie, 2011, 00:16:38 -

$00: 16: 39)$

Holmes has interfered with Moriarty's business on purpose, and he says that he is chased by Moriarty just like "cat and mouse" and "cloak and dagger" (Silver et al. \& Ritchie, 2011, 00:16:33$00: 16: 37)$. Watson makes fun of his analogies. He exchanges those analogies into "spider and fly" referring Moriarty as 
the spider and Holmes as the fly that one may assume that it is insulting. These metaphors are categorized as word-forword translation as they are translated literally into Indonesian with the same sentence structure, and Indonesian does not have the exact metaphor to substitute it for it is arbitrary (Pedersen, 2015).

\section{b. Substitution 1}

By applying this strategy, the ST metaphors are translated into the TT same conceptual metaphors which means that Indonesian has an equivalent metaphor in its natural language used by the natives (Pedersen, 2015). Some examples are shown in (8) and (9):

(8) ST: Dr. Watson: "Storm clouds were brewing over Europe."

TT: Dr. Watson: "Awan badai menyebar ke seluruh Eropa."

(Silver et al. \& Ritchie, 2011, 00:00:35 - 00:00:37)

In this case, "storm clouds" refers to the war tension between France and Germany. In Indonesian, we culturally understand when a war or a devastating occurrence is analogized into a bad weather. Take for example, "hati yang mendung" in Indonesian or "cloudy/gloomy heart" in English meaning that one is really sad uses the concept of cloudy weather to illustrate the sadness. This is why we have a similar metaphor.

Another example can be seen in (9),

(9) ST: Sherlock Holmes: "We're playing cat and mouse, the professor and I."

TT: Sherlock Holmes: "Kita bermain kucing dan tikus, profesor dan aku."

(Silver et al. \& Ritchie, 2011, 00:16:33 - 00:16:37)

In Indonesian, the metaphor of "cat and mouse" referring to "two people conflicting with each other" is natural and widely used. Thus, Indonesian has the equivalence for this. Substitution 1, in conclusion, results in a natural translated metaphor in TL system for Indonesian language recognizes the concept of the translated metaphor (Pedersen, 2015). Indonesian people are able to relate directly the real object to another object described in the movie which is said to be alike.

c. Substitution 2

This strategy transfers ST metaphors into TT different conceptual metaphors (Pedersen, 2015). For instance,

(10) ST: "When freedom triumphed over tyranny."

TT: "Ketika kemerdekaan menang atas kelaliman."

Back translation: "When freedom won over cruelty."

(Silver et al. \& Ritchie, 2011, 01:01:24 -

In this case, the translator translates "tyranny" into "kelaliman" or "cruelty" in English which is a synonym, but has a slightly different meaning. Thus, it is categorized into Substitution 2. Despite it, this Indonesian word is a non-standard diction according to The Great Indonesian Dictionary (Badan Pengembangan dan Pembinaan Bahasa, 2016). "Kezaliman" will be more proper.

\section{d. Paraphrase}

Paraphrasing is the second most applied strategy in which the ST metaphor is replaced with a non-metaphorical expression in this case. Hereby are some examples of them:

(11) ST: Sherlock Holmes: "He's the Napoleon of crime."

TT: Sherlock Holmes: "Dia penjahat kelas berat."

Back translation: "He's a heavyweight criminal."

(Silver et al. \& Ritchie, 2011, 00:07:30 00:07:35)

This analogy is translated by means of paraphrase into "penjahat kelas berat" or "a heavyweight criminal" or "a master criminal" in natural English. This Indonesian expression does not contain any metaphor within it. Instead, the researcher would suggest the translator to use "penjahat kelas kakap" or "a criminal 
of the snapper class" in literal English. This Indonesian expression is metaphorical and more natural. "Kakap" is a name of a big fish in Indonesian or "snapper" in English. This expression means "a master criminal" in English and is closer in terms of equivalence. Take for example, its antonym, "penjahat kelas teri" sounds natural in Indonesian, meaning "a petty criminal" in English. "Teri" is a name of a tiny fish in Indonesian or "anchovy" in English.

Another example can be seen in

(12) ST: Sherlock Holmes: "Then again, I'm knee-deep in research."

TT: Sherlock Holmes: "Aku terlalu sibuk dengan penelitianku."

Back translation: "I'm too busy with my research."

(Silver et al. \& Ritchie, 2011, 00:13:29 -

It is translated into a common expression without any metaphorical aspect in it. Indonesian does not have the equivalence for this. Hence, it is paraphrased. Paraphrasing make the translation natural in TL system. However, paraphrasing may lead to cultural meaning loss since the paraphrased metaphor is no longer metaphorical (Pedersen, 2015). Audiences understand the meaning, but they miss the cultural essence conveyed in the dialogue (lbid).

\section{e. Compensation 2}

There is no ST metaphor; thus, a metaphor from TT is added in this strategy. Hereby is the example as seen in (13):

(13) ST: Dr. Watson: "Well, according to your diorama, Professor James Moriarty."

TT: Dr. Watson: "Menurut talimu, Profesor James Moriarty."

Back translation: "According to your rope, Professor James Moriarty."
(Silver et al. \& Ritchie, 2011, 00:15:42 -

$00: 15: 48)$

In this scene, Holmes is showing Watson his mind map which is made from raffia ropes. He connects event by event from news articles, photos, and many more to find out the mastermind and his strategy. Watson concludes that all of those devastating events lead to Moriarty's doing. "Diorama" in English means "smallscale replica of a scene" according to Online Etymology Dictionary (Harper, 2010). Indonesian, in fact, borrows this term and uses it in the same form; hence, it means the same (Badan Pengembangan dan Pembinaan Bahasa, 2016). However, in Indonesia, this term is rarely used.

The translator compensates this by using an analogy from TL. The translator directly uses "your rope" analogizing diorama as it relates to the scene in which they are talking about this ideas web connected by the raffia ropes. The audiences will be able to relate the compensated analogy better than if the translator does otherwise by translating it into the borrowed word in Indonesian.

\section{CONCLUSION}

There are forty-two metaphors with thirty-two analogies, nine personifications, one image metaphor, and no proverb. Also, five strategies are applied by the subtitler of Sherlock Holmes 2: A Game of Shadows (2011) movie. They are eighteen metaphors with word-for-word translation $(42.86 \%)$, sixteen metaphors with paraphrase $(38.09 \%)$, six metaphors with substitution 1 (14.29\%), one metaphor with substitution $2(2.38 \%)$, and one metaphor with compensation 2 (2.38\%). No omission is applied. For further studies, this study could be developed by addressing visualized metaphors and applying quantitative method to enrich the data from the audiences' and translator's backgrounds and perspectives. 


\section{REFERENCES}

Badan Pengembangan dan Pembinaan Bahasa Kementerian Pendidikan dan Kebudayaan Republik Indonesia. (2016). KBBI Daring. Retrieved November 25, 2018, from https://kbbi.kemdikbud.go.id/

Biography.com Editors. (2014, April 2). Arthur Conan Doyle Biography. Retrieved November 25, 2018, from https://www.biography.com/ people/arthur-conan-doyle-9278600

Biography.com Editors. (2014a, April 2). Napoleon Biography. Retrieved November 24, 2018, from https://www.biography.com/people/napoleon-9420291

Dickins, J. (2005). Two Models for Metaphor Translation. Target 17(2), 227-273. doi: 10.1075/target.17.2.03dic

Dorothea. (2011, April 16). Sherlock Holmes: A Game of Shadows. Retrieved June 9, 2018, from https://subscene.com/subtitles/sherlock-holmes-a-game-of-shadows-2011/english/ 565098

Harper, D. (2010). Online Etymology Dictionary. Retrieved November 24, 2018, from https://www.dictionary.com/browse/diorama

IMDb. (2011, December 16). Sherlock Holmes: A Game of Shadows (2011). Retrieved October 16, 2018, from https://www.imdb.com/title/tt1515091/

Israel, M. (2014). Semantics: How Language Makes Sense. In Genetti, C. (Ed.), How Languages Work: An Introduction to Language and Linguistics (pp. 150-179). Cambridge: Cambridge University Press.

Lakoff, G. (1993). The Contemporary Theory of Metaphor. Metaphor and Thought (2nd ed.). University of California Berkeley.

Lu Shengli, M. (2009). Sherlock Holmes as a Romantic Detective: A Stylistic Analysis of Holmes's Use of Language (Master's thesis, National University of Singapore, 2009) (pp. 1-132). Singapore: National University of Singapore. Retrieved February 17, 2019, from https://scholarbank. nus.edu.sg/bitstream/10635/16892/1/Mark Lu Thesis.pdf.

Munday, J. (2016). Introducing Translation Studies: Theories and Applications. London: Routledge.

Nida, E. A. (1964). Towards a Science of Translating (2nd ed.). Leiden: Brill.

Pedersen, J. (2015). On the Subtitling of Visualized Metaphors. The Journal of Specialised Translation, 23(January), 162-180. Stockholm, Sweden: Stockholm University.

Samaniego Fernández, E., Velasco Sacristán, M., \& Fuertes Olivera, P.A. (2003). Translations We Live By: The Impact of Metaphor Translation on Target Systems. Paper presented at 8th International Cognitive Linguistics Conference (University La Rioja, 2025 July 2013), 61-81.

Schmidt, G. (2014). Metaphor Translation in Subtitling. Journal of Foreign Language Teaching and Applied Linguistics, 2(2). doi: 10.14706/jfltal15228

Silver, J et al. (Producers) \& Ritchie, G. (Director). (2011). Sherlock Holmes 2: A Game of Shadows [Motion picture on Blu-ray Disc]. USA: Warner Bros Pictures. 
Sherlock Holmes: A Game of Shadows (2011) Quotes. (n.d.). Retrieved June 9, 2018, from https://www.imdb.com/title/tt1515091/quotes/?tab=qt\&ref_=tt_trv_qu

Taheri-Ardali, M., Bagheri, M., \& Eidy, R. (2013). Towards a New Model to Metaphor Translation: A Cognitive Approach. Iranian Journal of Translation Studies, 11, 35-52. 